in these experiments : (1) the action of the light rays resulting from the discharge; (2) the action of the heat rays resulting from the discharge; (3) the action of germicidal substances formed in the air as a result of the discharge and then taken up in solution by the emulsion; and (4) the direct action of the electrical force itself on the bacteria and apart from concomitant chemical and other action. It was shown by experiment that any germicidal influence of either light or heat rays was negligible under the conditions of the experiments. The chemical substances formed in the air by the action of the discharge included nitrons and nitric compounds, and probably ozone and peroxide of hydrogen. The last two would be rapidly decomposed in the presence of nitrous compounds, and would probably be of importance chiefly in favouring the interaction of nascent nitrous and nitric compounds. Tubes of distilled water were then exposed to the action of the discharge under conditions similar to those prevailing in the former experiments, and after such exposure for 15 minutes the water was found to have taken up considerable quantities of nitrous and nitric acids, and to be capable of destroying bacteria immersed in it for periods of 15 minutes or less. Then solutions of potassium nitrite and nitric acid were made up such as would on admixture yield, after 15 minutes' interaction, an acidity equivalent to that of some of the specimens of distilled water which had been exposed to the discharge. And it was found that such a mixture, with an acidily equivalent to 0.05 per cent. of nitric acid, was capable of destroying all the bacteria which had previously been tested after an immersion of 15 minutes (solutions of nascent nitrous and nitric acids much more dilute than this have an efficient germicidal action). It was concluded, therefore, that under the con ditions of the experiments the germicidal action of these substances was sufficient to account for the results observed and without taking into consideration any possible direct effect of the electrical current itself.

Experiments were next carried out in order to ascertain whether the electrical current and discharge had of themselves, and without concomitant chemical action of the kind referred to, any effect on the bacteria under the time conditions of the experiments. The action of the current alone was tested by passing it directly through the bacterial emulsion without any preliminary discharge above the surface of the fluid by means of a platinum disc immersed just below the surface. It was found that if the germicidal action of heat was excluded an oscillatory current such as had been employed might be passed directly through the bacterial emulsion for as long as 60 minutes without obviously affecting the bacteria in any way.

Attempts were then made to test the possible action of the discharge above the bacterial emulsion, followed by the passage of the current through it by repeating our experiments in atmospheres of various pure gases-hydrogen, nitrogen, carbon dioxide, and carbon monoxide-in the hope of thus avoiding the complicating influence of chemical substances formed in common air as the result of the discharge. In many of these experiments, however, it was found that actively germicidal substances were formed in, or above, the emulsion and could be detected in solution at the end of the exposure. This result appeared to be caused in most instances by the presence of water vapour in the atmosphere in which the discharge occurred. It was found that in an atmosphere of hydrogen peroxide of hydrogen was formed in considerable quantities in some instances, and in some the probable germicidal action of nascent hydrogen had also to be taken into account; peroxide of bydrogen was also present in solution in considerable quantity in experiments in which the discharge was sprayed on to the bacterial emulsion through atmospheres of carbon monoxide and dioxide.

In experiments carried out in an atmosphere of pure nitrogen it was again found that nitrous and nitric compounds were formed and taken up in solution in quantity sufficient to destroy the bacteria present. In experiments of this nature, however, in which chemical changes due to the discharge in the gas above the emulsion were kept at a minimum, no germicidal action was manifested.

Conolusions. - In all the experiments in which a decided germicidal effect was observed it appeared that this was due entirely to the action of substances formed as the result of electrical action on the atmosphere in which the discharge occurred; and it appeared that under the time conditions of the experiments the electrical force employed was not capable of exercising any injurious action on the bacteria tested. And it is probable that when in medical practice cases of lupus and certain other cases in which there is an exposed ulcerated surface are treated by "high-frequency" discharges, the results produced are due entirely to the action on bacteria of nitrous and nitric acids formed in the neighbouring air. And from a therapeutic point of view the use of high frequency discharges in such cases must be looked upon mainly as an efficient method for bringing germicidal substances in a nascent and very active condition into contact with the bacteria present in the lesion exposed to the action of the discharge.

\section{NOTE ON A PECULIAR FORM OF HAMO- PTYSIS WITH PRESENCE OF NUMEROUS SPIROCH正TA IN THE EXPECTORATION.}

By ALDO CASTELLANI, M.D. FLORENCE, DIRECTOR OF THE CLINIC FOR TROPICAL DISEASES, COLOMBO

IN Ceylon I have come across two cases of a peculiar hæmorrhagic bronchitis which perhaps it may be of interest to publish. The first case was a man, a Cingalese, aged 44 years, who consulted me in April, 1904, believing himself to be affected with consumption. The symptoms were briefly as follows. He had a chronic cough which was generally more severe in the morning; expectoration was more or less abundant and muco-puralent in character; it was non-nummular and not bad smelling. Now and then for periods of two or three days, or even much longer, the expectoration contained blood, the blood being intimately mixed with the muco-pus and varying in amount; sometimes attacks of genuine hæmoptysis occurred, one or two tablespoonfuls of pure blood being expectorated. The patient had suffered from this complaint for two years. All the other members of his family were in good health and there was no history of syphilis. The disease had begun very gradually and without any apparent cause; his general condition had remained fairly good, although a certain degree of anæmia was noticeable; he had not wasted much. He did not complain of night sweats. He had observed rises of temperature, sometimes in the morning and sometimes in the evening.

By examining the mouth and making him spit and cough I satisfied myself that the blood did not come from the gums. The physical examination of the respiratory system, with the exception of a few moist râles at the base of both lungs, was negative. Nothing abnormal was detected in the heart and circulatory system, neither was anything abnormal noted on examination of the other organs. The analysis of the urine was negative. The microscopical investigation of the blood gave the following result: hæmoglobin (Fleish), 60; red blood cells, 4,000,000; and leucocytes, 11,000. An increase (21 per cent.) was noted in the large mononuclears, though there was no history of malaria. The sputum was examined three times for Koch's bacillus but always with negative results. The idea occurred to me that it might be a case of endemic bæmoptysis from distoma Ringeri. I made fresh preparations but no ova could be seen; on the other hand, huge numbers of spirochætæ-or what I thought at that time spirilla-were present. I did not then attach much importance to the observation ${ }^{1}$ and was inclined to believe the case to be one of tuberculosis, especially as it is well known that the bacillus of Koch may be often absent when the sputum is very hæmorrhagic. inoculated two guinea-pigs with the expectoration collected in sterile Petri dishes; both animals survived; one was killed two months after inoculation and no signs of tuberculosis were present.

I lost sight of the patient for more than a year during which time he constantly took one of the ordinary hypophosphite compounds I had prescribed. In July, 1905, he turned up again. His general condition had improved; he felt much stronger, though the chronic cough with bloodspitting had not sensibly diminished. Physical examination of the chest was again negative with the exception of

Spirilla or spirochreta have been occasionally seen in bronchial discharge by several authors long ago (Eichhorst, \&c.), but the parasites apparently were always present in small numbers only. 
a very few coarse moist râles as on the occasion of the first examination. The sputum was examined almost every day for three weeks but no tubercle bacilli could be found. Several guinea-pigs were also inoculated again with negative results. The expectoration, especially when much blood was present, was teeming with spirochætæ. The saliva and superficial scrapings from the gums were also examined; some spirochætæ were present but always in small numbers.

The second case was that of a male Indian. He presented symptoms similar to those of the first case; he had chronic cough with hæmorrhagic expectoration; also occasional attacks of hæmoptysis when a certain quantity of pure blood was spat up. According to the patient there had never been any fever and he had not wasted. He was extremely nervous ; in fact, he had become neurasthenic, thinking he was suffering from pulmonary tuberculosis. The physical examination of the chest showed only a few coarse moist râles on coughing in the lower part of both lungs. The sputum never contained tubercle bacilli and the guinea-pigs inoculated remained healthy. Spirochætæ were always present in great numbers, especially when blood and muco-pus were present in large amount. Spirochætæ could be found also in the saliva and scrapings from the gums but only in small numbers.

The spirochætæ were always very numerous and stained well by the Leishman method, generally taking up a bluish tint; they could be stained also with the ordinary aniline dyes, though not so well. They were generally mixed with some bacteria, but sometimes when the sputum was collected in sterile Petri dishes and preparations made at once they were practically the only germs present. Vincent's fusiform bacilli were never observed. These spirochætæ were not all alike. They might be divided morphologically into several groups. 1. Very thick individually, from 15 to 30 microns in length, with irregular waves which varied in number but were never very numerous. The parasites, with the Leishman method, stained deep blue; they were pointed at both ends. 2. Spirochætæ resembling the spirochæta refringens (Schaudinn) with a few graceful waves and pointed extremities. 3. Thin, delicate spirochætæ with numerous small, rather uniform waves and tapering ends. Sometimes one of the extremities was blunt while the other was pointed. 4. Very delicate parasites, though thicker than the spirochæta pallida, with very few waves generally irregular in shape.

All the types I have briefly described may be seen in tbe illustration. Similar types may be found, according to my

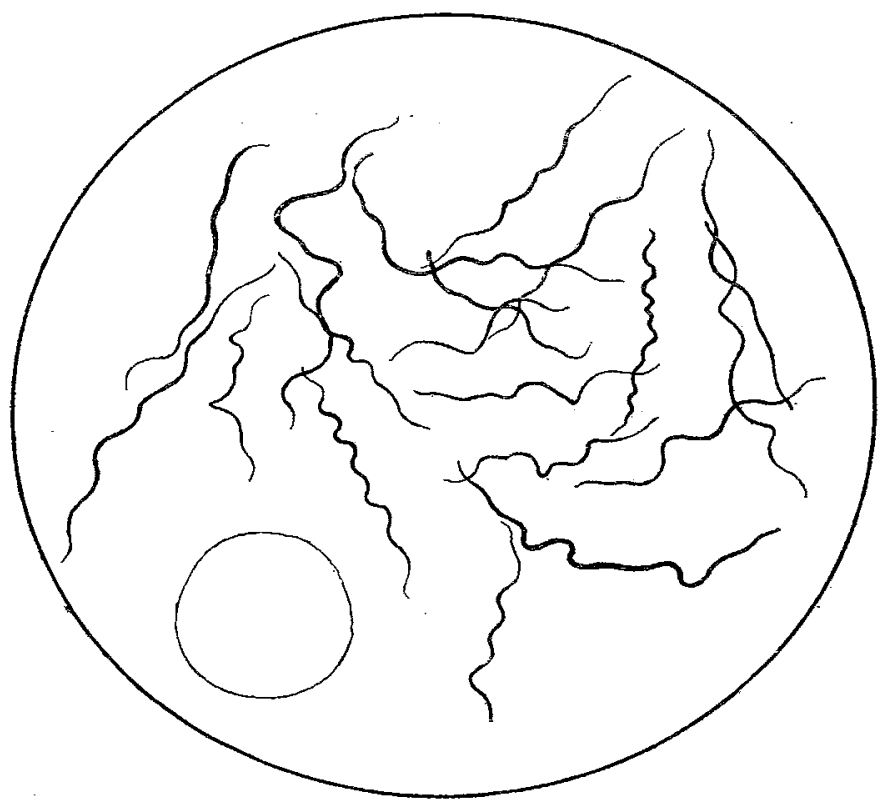

Showing the various forms of spirochætæ observed.

experience, also in spirochætæ observed in the mouth; it might be, therefore, that I had to deal with a bronchial or broncho-alveolar localisation of the spirochæta buccalis, which term, there is no doubt, covers many varieties of spirochætæ.

These two cases of hæmorrhagic bronchitis are of an obscure nature; it seems to me that they cannot be considered of a tuberculous origin. The microscopical examination excludes the possibility of a form of endemic hæmoptysis from distomum Ringeri. It might be suggested, perhaps, that possibly the spirochætæ present in such large numbers in the expectoration-sometimes practically without other germs-may have had a part in the etiology of the complaint. It is interesting to note that Plimmer has noticed in guinea-pigs a peculiar form of pseudo-tuberculosis and that in the smears taken from the pseudo-tuberculous lesions he found numerous spirochætæ.

Colombo.

\section{HYPERTROPHY AND DILATATION OF THE HEART IN A CHILD WITHOUT VALVULAR DISEASE OR GENERAL ADHESION OF THE PERI- CARDIUM.'}

By GEORGE CARPENTER, M.D. LOND., M.R.C.P. LOND., PHYSICIAN TO THE NORTH-EASTERN HOSPITAL FOR CHILDREN; AND

THEODORE FISHER, M.D. LOND., M.R.C.P. LOND., ASSISTANT PHYSICIAY TO THE EAST LONDON HOSPITAL FOR CHILDREN.

OCCASIONALLY cases of death from cardiac disease are seen in the post-mortem room not only in adults but also in children in which the ordinary well-recognised morbid affections of the heart are absent. Although such cases are rare, at least in children, that they do not attract attention more often is no doubt due to the fact that the idea that even slight degrees of mitral regurgitation are sufficient to account for death is deeply sunken in the medical mind. An apical systolic murmur has been heard during life and after death deformity of the mitral cusps is looked for and not perhaps uncommonly found without sufficient reason. One often hears of the expression "thickened edge of mitral" as if the thickened edge were sufficient to account for death. The so-called thickened edge is frequently merely the normal thickening which is situated where interlacing of the fibres of the chordæ tendineæ takes place at their insertion into the mitral cusps. This is made perfectly clear on holding up the large mitral cusp against the light, when the course of the fibres of the chordæ tendinea between the layers of endocardium forming the cusp can be readily seen. Although, however, we have frequently seen this normal band of thickening considered to be evidence of disease it is needless to say that abnormal thickening may be present in the same situation. When thickening of the mitral valve occurs it affects the fibres of the chordæ tendineæ from their origin at the apices of the musculi papillares to their termination at the mitral ring. As might be expected, this thickening of the fibres of the chord tendineæ is most evident where the normal interlacing takes place-that is, at their insertion into the cusps of the mitral valve. Such a band of thickening cannot, however, interfere with the action of the valve. Should regurgitation be present it is generally mainly due to shortening of the chordæ tendineæ, which shortening prevents efficient closure of the cusps. Slight degrees of mitral regurgitation can, however, hardly account for death and certainly cannot explain considerable general dilatation of the heart.

In the case recorded below slight thickening of the mitral cusps of the character which we have indicated was present, but was not sufficient in degree to have interfered in any way with the action of the valve. Mitral regurgitation was present, but in this case it was secondary to dilatation of the orifice, not to shortening of the chordæ tendineæ. The following are brief notes.

A boy, aged eight years, was sent to the North-Eastern Hospital for Children on Sept. 10th, 1905, by Dr. John Spurway of Brondesbury to be admitted under the care of one of us (G. O.). One year previously the boy had suffered from slight "heart trouble," and four montbs before admission there had been swelling of the elbows, knees, and bands. On admission the cardiac impulse was in the left fifth interspace outside the nipple line. A systolic murmur was present at the apex and a

I A paper read before the Society for the Study of Disease in Children on Jall. 19th, 1906. 